\title{
Mosaics of canopy openness induced by tropical cyclones in lowland rain forests with contrasting management histories in northeastern Australia
}

\author{
SIMON J. GROVE, STEPHEN M. TURTON ${ }^{1}$ and \\ DANNY T. SIEGENTHALER
}

Rainforest Cooperative Research Centre, School of Tropical Environment Studies and Geography, James Cook University, PO Box 6811, Cairns, Qld. 4870, Australia

(Accepted 21st June 2000)

\begin{abstract}
Tropical Cyclone 'Rona' crossed the coast of the Daintree lowlands of northeastern Australia in 1999. This study reports on its impact on forest canopy openness at six lowland rain forest sites with contrasting management histories (old-growth, selectively logged and regrowth). Percentage canopy openness was calculated from individual hemispherical photographs taken from marked points below the forest canopy at nine plots per site 3-4 mo before the cyclone, and at the same points a month afterwards. Before the cyclone, when nine sites were visited, canopy openness in old-growth and logged sites was similar, but significantly higher in regrowth forest. After the cyclone, all six revisited sites showed an increase in canopy openness, but the increase was very patchy amongst plots and sites and varied from insignificant to severe. The most severely impacted site was an old-growth one, the least impacted a logged one. Although proneness to impact was apparently related to forest management history (old-growth being the most impacted), underlying local topography may have had an equally strong influence in this case. It was concluded that the likelihood of severe impact may be determined at the landscape-scale by the interaction of anthropogenic with meteorological, physiographic and biotic factors. In the long term, such interactions may caution against pursuing forest management in cyclone-prone areas.
\end{abstract}

KEY WORDS: Australia, canopy openness, cyclone, disturbance, hemiphots, management history, patch dynamics, rain forest, tropical

\section{INTRODUCTION}

Tropical cyclones (also known as hurricanes and typhoons) play a significant disturbance and maintenance role in rain forests across the non-equatorial tropics (Boose et al. 1994, Webb 1958, Whitmore 1974). All major tropical

\footnotetext{
${ }^{1}$ To whom correspondence should be addressed. Email: steve.turton@jcu.edu.au
} 
oceans and adjacent land areas, except the South Atlantic, experience these weather systems, particularly during the summer and early autumn months (McGregor \& Nieuwolt 1998). In northeastern Australia the 'cyclone season' occurs between November and April, although cyclones have been reported in the South West Pacific as early as September and as late as June (Sturman \& Tapper 1996).

Tropical cyclones range in intensity from comparatively weak systems (Categories 1-2), where maximum wind speeds do not generally exceed 160 $\mathrm{km} \mathrm{h}^{-1}$, to extremely destructive systems (Categories 3-5) where wind speeds have been recorded in excess of $350 \mathrm{~km} \mathrm{~h}^{-1}$ (McGregor \& Nieuwolt 1998). Severe cyclones often cause widespread defoliation of rain forest canopy trees, removal of vines and epiphytes, along with the breakage of crown stems and associated tree falls (Bellingham et al. 1995, Boose et al. 1994, Brokaw \& Walker 1991, Everham \& Brokaw 1996, Lugo et al. 1983, Tanner et al. 1991). These catastrophic impacts typically result in significant changes in forest microclimates (Bellingham et al. 1996, Fernandez \& Fetcher 1991, Turton 1992), and complex vegetation responses to newly created light, temperature and humidity regimes (Bellingham et al. 1994, Harrington et al. 1997, Vandermeer et al. 1995).

Given the relatively high frequency of tropical cyclones (McGregor \& Nieuwolt 1998), there is a general consensus that they contribute to the structure and function of tropical rain forests in cyclone-prone areas, with ecosystem impacts and recovery processes occurring at several spatial scales (Bellingham 1991, Bellingham et al. 1992, 1994, 1995; Harrington et al. 1997, Webb 1958; Whitmore 1989, 1991; Yih et al. 1991). Boose et al. (1994) examined the impacts of severe hurricanes on forested landscapes in the northeastern United States and Puerto Rico and concluded that wind damage served as an important source of landscape-scale $(\approx 10 \mathrm{~km})$ patterning in forests and was a major factor initiating vegetation dynamics at that scale. On the other hand, at the stand-scale $(\approx 1 \mathrm{~km})$, extensive blowdown was considered to be an important factor regulating hydrological, energy and nutrient regimes (Boose et al. 1994).

At the stand-scale variations in wind conditions during the passage of a tropical cyclone are largely due to individual wind gusts created by turbulent eddies, and wind gradients associated with the intense convective cells and sometimes with tornadoes (Boose et al. 1994). Changes in the wind flow may result from small-scale topographic features and from the structure of the forest itself. In comparison, at the landscape-scale, three main factors control forest damage (Boose et al. 1994): (1) wind velocity gradients resulting from cyclone size and intensity and proximity to the storm track, complicated by local convective-scale effects; (2) variations in site exposure and other effects of local topography; and (3) differential response of individual ecosystems to wind disturbance as a function of species composition and forest structure.

Despite some excellent research on impacts of tropical cyclones on forests, 
there have been no studies documenting the landscape-scale impacts of cyclones on rain forests under different management regimes. Such research is warranted given the fact that many tropical rain forest areas of the world are subject to a variety of management systems, ranging from strict protection to selective logging to clear felling (Just 1991, Whitmore 1990). In addition, the subject of disturbance interactions is poorly documented (Willig \& Walker 1999), and often largely speculative, so any study that attempts to quantify interactions between past human disturbance and cyclone damage to rain forests will provide valuable insights to ecologists and foresters alike.

The primary aim of this study was to quantify the impacts of Severe Tropical Cyclone 'Rona' (February 1999) on the rain forests of the Daintree lowlands in northeastern Australia. Canopy openness before and after the cyclone, as determined from hemispherical photographs, was compared at sites across the region impacted by the cyclone. A second aim was to assess the effect, if any, of the previous management history of the sites (classified as old growth, logged and re-growth) on canopy openness following the cyclone.

\section{METHODS}

\section{Study area}

The Daintree lowlands form a narrow coastal belt, between latitudes $16^{\circ} 00^{\prime}$ and $16^{\circ} 18^{\prime} \mathrm{S}$ and longitudes $145^{\circ} 20^{\prime}$ and $145^{\circ} 30^{\prime} \mathrm{E}$, lying between the Coral Sea to the east and the Thornton uplands which rise steeply to 400-1368 m altitude immediately to the west (Figure 1). Several spurs of hills run westeast from the main upland massif, increasing local topographical complexity by more or less dividing the lowlands into a series of semi-enclosed coastal basins. The region experiences a humid tropical monsoonal climate, with high but variable annual rainfall ranging from 2000-4000 mm (Tracey 1982). Whilst most of this falls in summer (December-March) when the monsoonal trough is active over the region, winters are seldom dry due to orographic uplift associated with the almost perpendicular southeasterly trade winds. Mean daily temperatures range from $28{ }^{\circ} \mathrm{C}$ in January to about $22{ }^{\circ} \mathrm{C}$ in July, and relative humidity remains above $60 \%$ throughout the year, averaging $78 \%$ in the summer months (Tracey 1982).

Much of the region's rain forest is classified as complex mesophyll vine forest types $1 \mathrm{a}$ and $2 \mathrm{a}$ in the schema of Tracey (1982), comprising closed, largely evergreen forest with an uneven canopy 20-40 m high, with occasional emergents to $45 \mathrm{~m}$. Plank buttresses, woody lianes, vascular epiphytes and tree palms are prominent. The soils and underlying geology range from rudimentary podsols derived from deep alluvium and recent marine sediments on flatter ground, through well-weathered red podsols derived from phyllites and schists on the lower slopes, to skeletal lithosols, yellow earths and boulder-fields derived from coarser schists and granites on the steeper foothills (Date \& Ross 1985). Most of the forest on the steeper slopes retains the characteristics of 


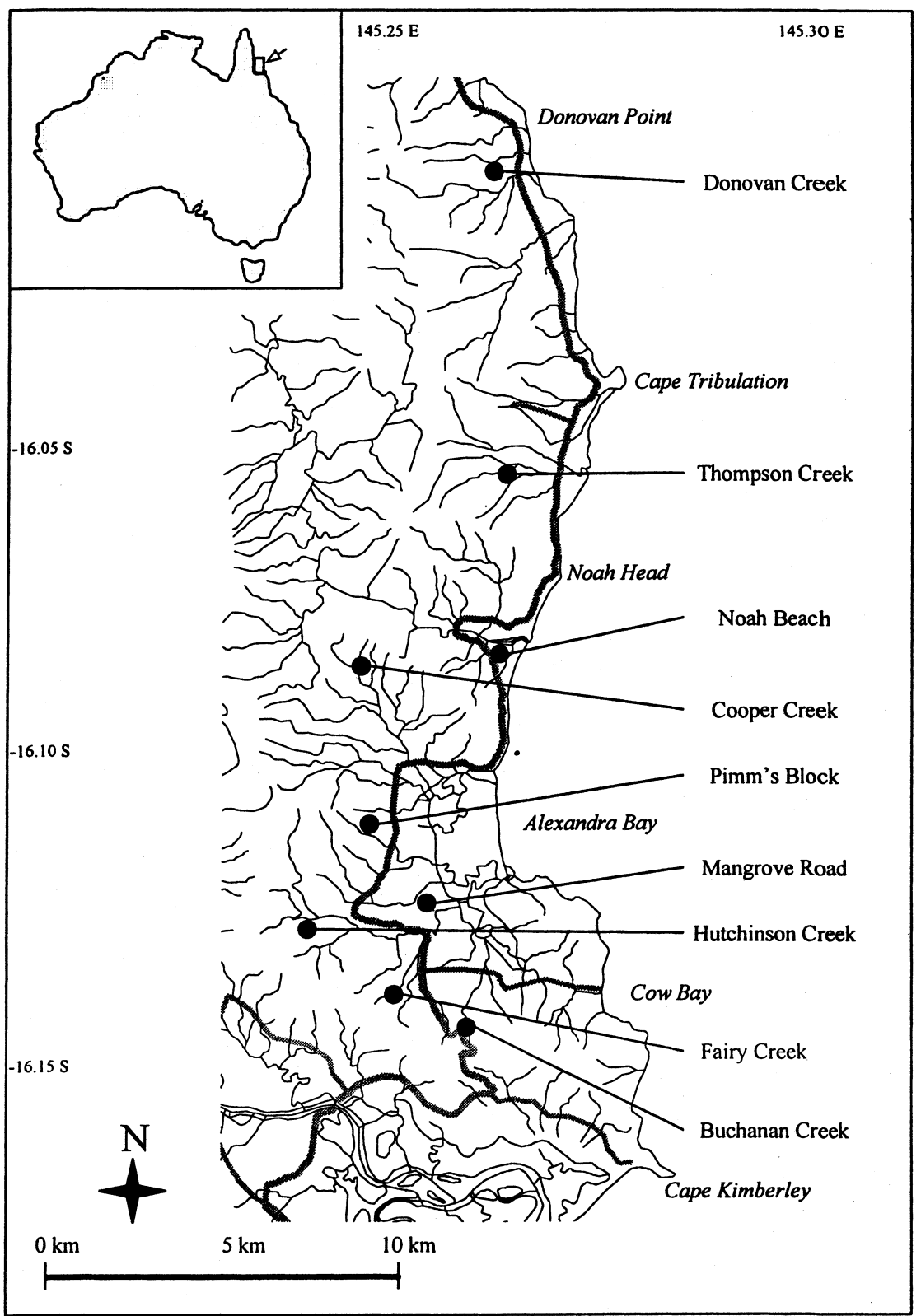

Figure 1. The study area showing location of nine study sites across the Daintree Lowlands, northeastern Australia.

old-growth forest, with at most only a few scattered red cedar (Toona ciliata M. Roemer) trees having been felled over a century ago (Frawley 1991). Most of the gentler slopes have been subjected to rather ad hoc selective logging which continued over several decades until the late 1980s, when most logging ceased. The coastal flats have a history of more intensive use, with large areas having 
been cleared of rain forest, either by Aborigines (for firestick farming, Hill et al. 1999) or by early European settlers (chiefly for grazing). Many such areas have reverted to re-growth forest over the past 30-90 y.

\section{Cyclone 'Rona'}

Severe Tropical Cyclone 'Rona' (low Category 3), with a central pressure of 975 Hpa, crossed the northeastern Australian coast between Noah Head and Cape Kimberley (Figure 1) on 11 February, 1999. The cyclone was tracking north-west at about $15 \mathrm{~km} \mathrm{~h}^{-1}$ when it crossed the coast with maximum wind gusts of $180 \mathrm{~km} \mathrm{~h}^{-1}$ near the centre (Bureau of Metorology 1999). Sustained (1-min average) winds were above $120 \mathrm{~km} \mathrm{~h}^{-1}$, but varied significantly due to effects of steep terrain in the Daintree-Cape Tribulation area. The zone of very destructive (hurricane force) winds extended only $15 \mathrm{~km}$ from the centre of the cyclone, with destructive winds (storm force) extending some $80 \mathrm{~km}$ from the centre (Bureau of Meteorology 1999). As a consequence, all the rain forest areas of the Greater Daintree region (Figure 1) were impacted by the cyclone to varying degrees. This was the first severe cyclone to cross over the Daintree region since 1912 (Bureau of Meteorology 1999).

\section{Experimental design}

For the purposes of this study, three 'treatments', based on land-use history as described above, were recognized: old-growth, logged and re-growth. Within each treatment, three sites were selected a priori, separated by at least $3 \mathrm{~km}$ of continuous forest - a total of nine sites (Figure 1, Table 1). Within each site, nine forest plots were selected for hemispherical photography, spaced every 50 m along a 400-m 'internal transect'. All sites were located at least $100 \mathrm{~m}$ from the nearest road or clearing, to reduce likely 'edge effects' associated with such features (Murcia 1995).

Hemispherical photographs (hemiphots) were taken at each plot $(\mathrm{n}=81$, i.e. $9 \times 9$ sites) 3-4 mo before Cyclone Rona, using the method and photographic equipment described in Turton (1992). Despite the precaution of bracketing exposures, light conditions at the time of photography were such that data for

Table 1. Physical attributes for the nine study sites, located across the Daintree lowlands, northeastern Australia. L, logged; O, old-growth; R, re-growth rain forest.

\begin{tabular}{|c|c|c|c|c|c|}
\hline \multirow[b]{2}{*}{ Site name } & \multirow[b]{2}{*}{ Treatment } & \multicolumn{2}{|c|}{ Location } & \multirow[b]{2}{*}{ Elevation $(\mathrm{m})$} & \multirow[b]{2}{*}{ Aspect } \\
\hline & & Lat. $16^{\circ} \mathrm{S}$ & Long. $145^{\circ} \mathrm{E}$ & & \\
\hline Thompson Creek (TC) & $\mathrm{O}$ & $06^{\prime} 31^{\prime \prime}$ & $26^{\prime} 25^{\prime \prime}$ & 80 & NE \\
\hline Buchanan Creek (BC) & $\mathrm{O}$ & $14^{\prime} 39^{\prime \prime}$ & $25^{\prime} 54^{\prime \prime}$ & 140 & $\mathrm{NE}$ \\
\hline Cooper Creek (CG) & $\mathrm{O}$ & $09^{\prime} 10^{\prime \prime}$ & $24^{\prime} 19^{\prime \prime}$ & 140 & $\mathrm{~S}$ \\
\hline Fairy Creek (FC) & $\mathrm{L}$ & $14^{\prime} 16^{\prime \prime}$ & $24^{\prime} 57^{\prime \prime}$ & 80 & NW \\
\hline Hutchinson Creek (HC) & $\mathrm{L}$ & $13^{\prime} 04^{\prime \prime}$ & $23^{\prime} 57^{\prime \prime}$ & 30 & 0 \\
\hline Pimm's Block (PB) & $\mathrm{L}$ & $11^{\prime} 20^{\prime \prime}$ & $24^{\prime} 18^{\prime \prime}$ & 100 & $\mathrm{E}$ \\
\hline Donovan Greek (DC) & $\mathrm{R}$ & $01^{\prime} 13^{\prime \prime}$ & $26^{\prime} 38^{\prime \prime}$ & 20 & 0 \\
\hline Mangrove Road (MR) & $\mathrm{R}$ & $12^{\prime} 42^{\prime \prime}$ & $25^{\prime} 18^{\prime \prime}$ & 10 & 0 \\
\hline Noah Beach (NB) & $\mathrm{R}$ & $09^{\prime} 04^{\prime \prime}$ & $26^{\prime} 27^{\prime \prime}$ & 10 & 0 \\
\hline
\end{tabular}


six plots at one of these sites (Mangrove Road) had to be discarded before analysis. One month after the cyclone, six of the original nine sites (two for each treatment) were re-visited and hemispherical photographs taken at exactly the same plot locations. In summary, paired (i.e. before and after cyclone) hemiphots from 48 forest plots were available for analysis, representing six of the original nine study sites spread across the region.

\section{Analysis}

Once the hemiphots were digitized, brightness levels were adjusted by eye so as to maximize the contrast between canopy and sky (cf. Whitmore et al. 1993). The hemiphots were then analysed using the Winphot software package (ter Steege 1996). Canopy openness, expressed as a percentage of the amount of sky visible at the centre of each plot, was calculated for the pre- and postcyclone data sets. Statistical analyses were conducted under the General Linear Model in SPSS for Windows (SPSS 1999).

\section{RESULTS}

A nested analysis of variance (ANOVA) of pre-cyclone canopy openness for all available plots in all nine sites indicated a significant effect of treatment $(\mathrm{P}=$ $0.001)$ but no significant effect of site within treatment $(P=0.397)^{1}$. The source of most of this variation lay in the difference between the responses of regrowth forest compared to the other two treatments (Figure 2). Re-growth forest tends to have significantly greater canopy openness than the other two treatments (post-hoc Bonferroni tests: $\mathrm{P}=0.002$ for re-growth and old-growth; $\mathrm{P}=0.035$ for re-growth and logged). No such significant differences in canopy openness before the cyclone existed between logged and old-growth forest.

Figure 2 compares mean canopy openness (\%) for the nine sites before and six sites after Cyclone Rona. All six sites experienced an increase in canopy openness after the cyclone, with the smallest and highest increase at Fairy Creek (logged) and Thompson Creek (old-growth), respectively (Figure 3).

A nested split-plot $\mathrm{ANOVA}^{2}$ was conducted based on all 48 forest plots for which pre- and post-cyclone data are available. Variation between years was highly significant $(\mathrm{F}=58.3$, df $=1 ; \mathrm{P}<0.001)$, indicating a strong overall effect of Cyclone Rona on canopy openness. Highly significant effects of year by treatment $(\mathrm{F}=8.07, \mathrm{df}=2 ; \mathrm{P}=0.001)$ and year by site within treatment $(\mathrm{F}=7.162$, df $=3 ; \mathrm{P}<0.001)$ further indicate that the responses of individual sites to the cyclone differed greatly, apparently partially governed by treatment-level responses.

\footnotetext{
${ }^{1}$ (Type III sum of squares for unbalanced design due to fewer useable plots at Mangrove Road; F = 7.693, $\mathrm{df}=2$, for treatment; $\mathrm{F}=1.057, \mathrm{df}=6$ for site within treatment; error $\mathrm{df}=66$; total $\mathrm{df}=75$; corrected total $\mathrm{df}=74$.)

${ }^{2}$ Type I sum of squares, with treatment and year as fixed effects, site-within treatment and plot-within-site-within treatment as random effects, and with canopy openness as the dependent variable.
} 


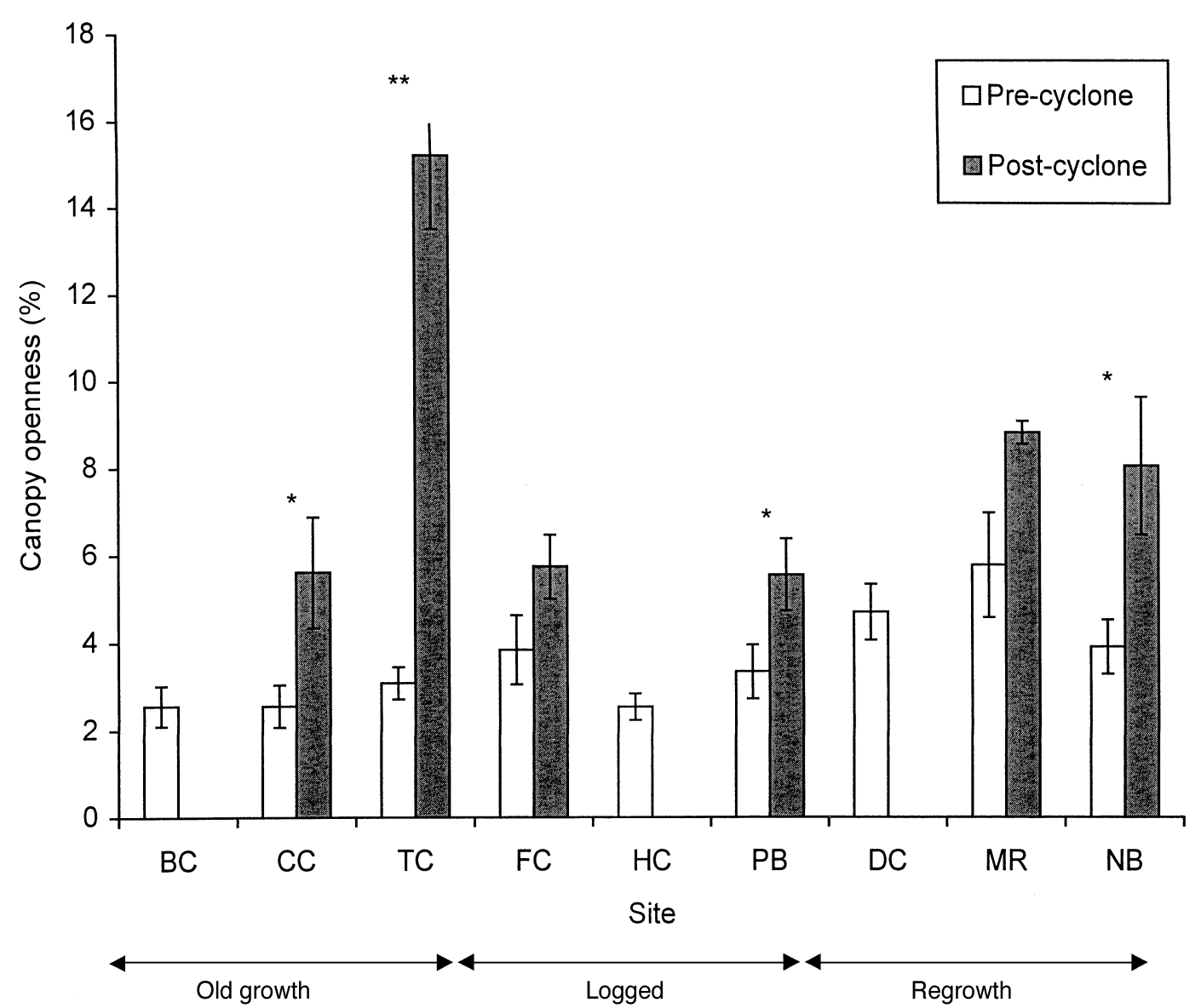

Figure 2. Canopy openness (\%) before and after Cyclone Rona for all plots used in this study. Values shown are means \pm SEs. Sites for which pre- and post-cyclone openness differed significantly in one-way ANOVAs are asterisked $(* *, \mathrm{P}<0.001 ; *, \mathrm{P}<0.05)$. Site name abbreviations are shown in full in Table 1 . Post-cyclone data were not available for BC, DC and HC.

One-way ANOVAs of canopy openness values, conducted on a site-by-site basis, confirmed that changes in canopy openness due to Cyclone 'Rona' were significant $(0.01<\mathrm{P}<0.05)$ at Cooper Creek (old-growth), Pimm's Block (logged) and Noah Beach (re-growth) $(\mathrm{F}=5.03,4.66$ and 5.98 respectively). For Thompson Creek (old-growth), changes were highly significant $(\mathrm{P}<0.001)$ $(\mathrm{F}=48.6)$, while changes were marginally insignificant $(0.05<\mathrm{P}<0.1)$ at Fairy Creek (logged) and Mangrove Road (regrowth) ( $\mathrm{F}=3.14$ and 6.13 respectively).

\section{DISGUSSION}

This study has shown that there are complex patterns of damage associated with the impact of a severe tropical cyclone on the rain forests of the Daintree 

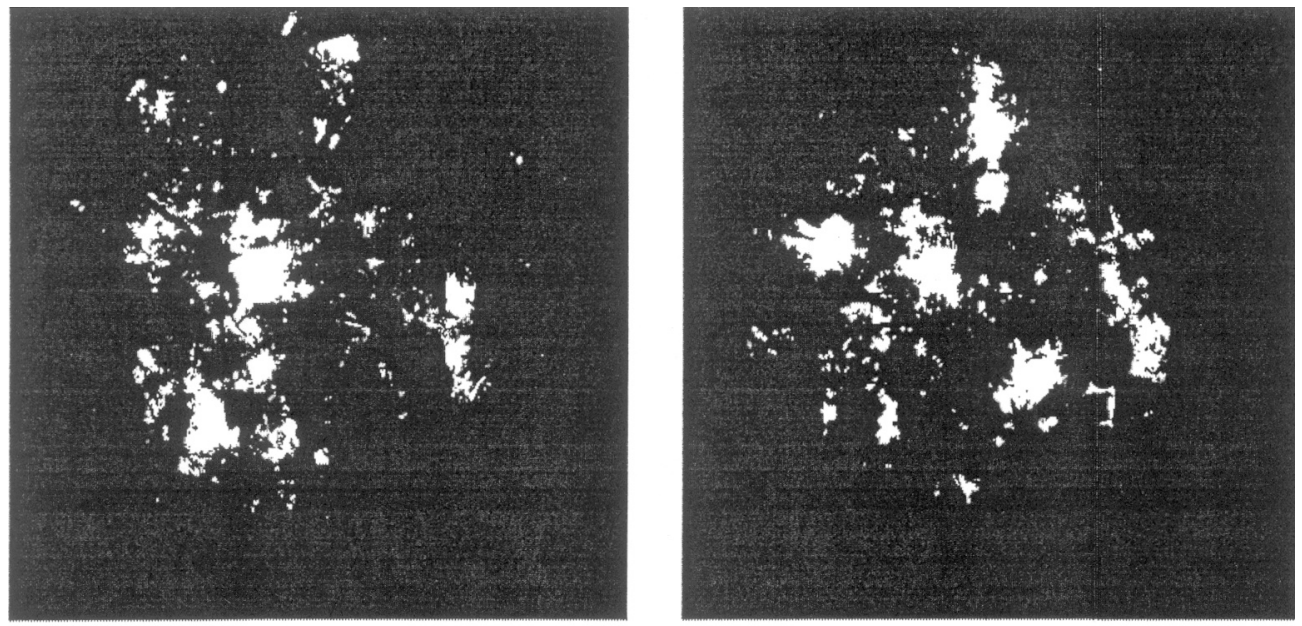

(a)
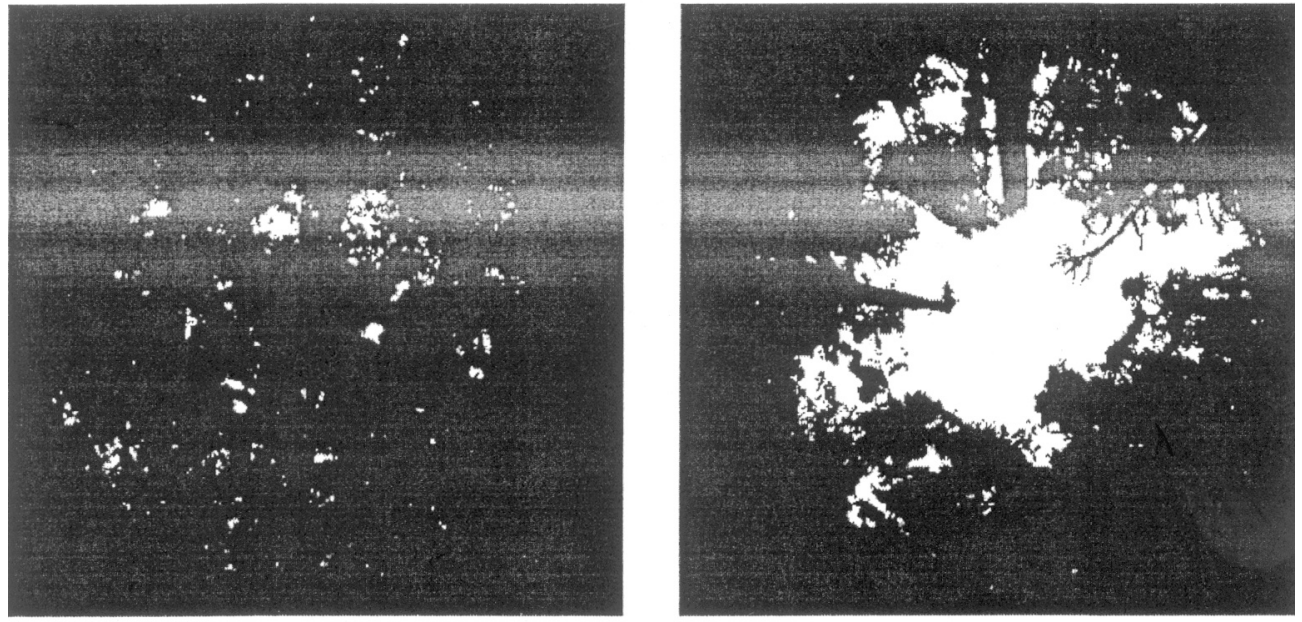

(b)

Figure 3. Hemispherical photographs (hemiphots) of two plots before and after Cyclone Rona: (a) insignificant change in canopy openness (Fairy Creek); (b) highly significant increase in canopy openness (Thompson Creek).

region of northeastern Australia. In particular, we have examined impacts at the landscape- and stand-scales for rain forests with contrasting management histories. Our results confirm that the destruction of the forest canopy across the Daintree region was very patchy, a phenomenon observed in tropical forest areas elsewhere (e.g. Boose et al. 1994). There is a suggestion that this variability was determined by prior treatment (management history): both old-growth sites that were revisited suffered significant damage (one of them the most 
severe recorded during this study), whereas only one each of the logged and regrowth sites were significantly affected (though the remaining two sites also showed some non-significant effects). It thus appears that a history of selective logging need not predispose a site to an unnaturally high degree of cyclone damage. Indeed, it could even be argued that logging in our study area reduced its susceptibility to cyclone damage, perhaps by removing the large, top-heavy trees most prone to being toppled. However, this interpretation should be treated with great caution, given the small number of study sites, and managers of rain forests in cyclone-prone regions should not be complacent with regard to the effects of cyclones (Webb 1958). Furthermore, the widespread belief that some forms of selective logging are environmentally benign because they are assumed to mimic the effects of windthrow (e.g. Nicholson et al. 1990, Whitmore 1990) clearly has its limits, especially in cyclone-prone areas. For instance, logging seeks to remove the trees felled whereas cyclones create a surge of dead wood whose value for rain forest biodiversity and to ecosystem processes is only now beginning to be understood (Chambers et al. 2000, Grove \& Stork 1999, Pinard \& Cropper 2000).

Two scenarios are possible whereby logging and cyclones may give rise to long-term interactive effects (Willig \& Walker 1999). (1) If logging dampens the forest's natural disturbance response to cyclones, as our results seem to suggest, then organisms whose ecologies are tuned to take advantage of pulsed responses to temporal and spatial changes in habitat availability, such as invertebrates and fungi opportunistically colonizing dead wood, may be at a competitive disadvantage compared to those favouring more steady-state conditions. If biological diversity in such groups is maintained by such stochastic events (Grossman et al. 1982, Hugueny \& Cornell 2000, Ostfeld \& Keesing 2000, Sturtevant et al. 1997), then it could decline in logged forest if surges of dead wood availability are no longer able to occur. (2) Alternatively, or perhaps additionally, a recently logged forest with an already open canopy could have its canopy opened up further by a cyclone to such an extent as to change its successional trajectory towards a more disturbance-tolerant plagioclimax, to the disadvantage of forestry as well as to biological conservation. Such a scenario might only develop in regions experiencing more frequent cyclones than occurred in the Daintree lowlands throughout the 20th century, but cyclones are notoriously irregular and what is typical of one century may be atypical in the longer term (McGregor \& Nieuwolt 1998).

It is perhaps more likely that the impacts of Cyclone 'Rona' on canopy openness were determined by the interaction of meteorological, physiographic and biotic factors (Boose et al. 1994), and that the apparent relationship with treatment is spurious. Variations in wind conditions at the landscape-scale are generally greatest in the vicinity of the eyewall of the cyclone, and near intense convective cells and tornadoes (if they occur) in other parts of the cyclone. Significant variation in forest damage may also 
be caused by abrupt changes in surface friction (e.g. along coastlines) or by local topography (Boose et al. 1994). Topographic effects at this scale are very complex and may include acceleration of the wind over ridges and summits, with strong turbulence on the lee sides (e.g. Thompson Creek, Figure 3), wind channelling up valleys and around protuberances, and variations in exposure due to wind shadowing (e.g. Fairy Creek, Figure 3). To varying degrees, all of these factors seem to have played a role in the impact of Cyclone 'Rona' on the Daintree lowlands.

This paper has provided some insights into interactions between anthropogenic and natural disturbance in lowland tropical rain forest in northeastern Australia, but much remains to be researched, in this region and elsewhere. Future studies in the Daintree lowlands will focus on canopy recovery and associated responses of understorey and mid-canopy vegetation to changing microclimate regimes across the 48 sample plots.

\section{ACKNOWLEDGEMENTS}

The authors wish to thank the many volunteer field assistants who helped out before Cyclone Rona. Nigel Young assisted with digitizing and analysing the hemiphots, and Steve Delean and Michael Steele provided statistical advice.

\section{LITERATURE CITED}

BELLINGHAM, P. J. 1991. Landforms influence patterns of hurricane damage: evidence from Jamaican montane forests. Biotropica 23:427-433.

BellinghaM, P. J., KAPOS, V., VARTY, N., HEAlEY, J. R., TANNER, E. V. J., KELly, D. L., DALLING, J. W., BURNS, L. S., LEE, D. \& SIDRAK, G. 1992. Hurricanes need not cause high mortality: the effects of Hurricane Gilbert on forests in Jamaica. Journal of Tropical Ecology 8:217223.

BELLINGHAM, P. J., TANNER, E. V. J. \& HEALEY, J. R. 1994. Sprouting of trees in Jamaican montane forests after a hurricane. Journal of Ecology 82:747-758.

BELLINGHAM, P. J., TANNER, E. V. J. \& HEALEY, J. R. 1995. Damage and responsiveness of Jamaican tree species after disturbance by a hurricane. Ecology 76:2562-2580.

BELlinghaM, P. J., TANNER, E. V. J., RICH, P. M. \& GOODLAND, T. C. R. 1996. Ghanges in light below the canopy of a Jamaican montane rain forest after a hurricane. Journal of Tropical Ecology 12:699-722.

BOOSE, E. R., FOSTER, D. R. \& FLUET, M. 1994. Hurricane impacts to tropical and temperate forest landscapes. Ecological Monographs 64:369-432.

BROKAW, N. V. L \& WALKER, L. R. 1991. Summary of the effects of Caribbean hurricanes on vegetation. Biotropica 23:442-447.

BUREAU OF METEOROLOGY 1999. Annual Report 1998-99. Commonwealth of Australia, Canberra.

CHAMBERS, J. Q., HIGUCHI, N., SCHIMEL, J. P., FERREIRA, L. V. \& MELACK, J. M. 2000. Decomposition and carbon cycling of dead trees in tropical forests of the central Amazon. Oecologia 122:380-388.

DATE, R. A. \& ROSS, D. J. 1985. Altitudinal transect studies at Cape Tribulation, North Queensland. III. Notes on soils from the general sampling sites. Queensland Naturalist 26:53-57.

EVERHAM, E. M. \& BROKAW, N. V. L. 1996. Forest damage and recovery from catastrophic wind. Botanical Review 62:113-173.

FERNANDEZ, D. S. \& FETCHER, N. 1991. Changes in light availability following Hurricane Hugo in a subtropical montane forest in Puerto Rico. Biotropica 23:393-399. 
FRAWLEY, K. 1991. Past rain forest management in Queensland. Pp. 85-104 in Werren, G. \& Kershaw, $\mathrm{P}$. (eds). The rain forest legacy: volume 3 - rain forest history, dynamics and management. Australian Government Publishing Service, Canberra.

GROSSMAN, G. D, MOYLE, P. B. \& WHITAKER, J. O. JR. 1982. Stochasticity in structural and functional characteristics of an Indiana stream fish assemblage: a test of community theory. American Naturalist 120:423-54.

GROVE, S. J. \& STORK, N. E. 1999. The conservation of saproxylic insects in tropical forests: a research agenda. Journal of Insect Conservation 3:67-74.

HARRINGTON, R. A., FOWNES, J. H, SCOWCROFT, P. G. \& VANN, C. S. 1997. Impact of Hurricane Iniki on native Hawaiian Acacia koa forests: damage and two-year recovery. Journal of Tropical Ecology 13:539-558.

HILL, R., BAIRD, A. \& BUCHANAN, D. 1999. Aborigines and fire in the wet tropics of Queensland, Australia: ecosystem management across cultures. Society and Natural Resources 12:205-223.

HUGUENY, B. \& CORNELL, H. V. 2000. Predicting the relationship between local and regional species richness from a patch occupancy dynamics model. Journal of Animal Ecology 69:194-200.

JUST, T E. 1991. Management of tropical rain forests in North Queensland. Pp. 228-239 in McKinnell, F. H., Hopkins, E. R. \& Fox, J. E. D. (eds). Forest management in Australia. Surrey Beattie \& Sons, Sydney.

LUGO, A. E., APPlefield, M., POOL, D. J. \& MCDONALD, R. B. 1983. The impact of Hurricane David on the forests of Dominica. Canadian Journal of Forest Research 13:201-211.

MCGREGOR, G. R. \& NIEUWOLT, S. 1998. Tropical climatology: an introduction to the climates of the low latitudes (Second Edition). John Wiley \& Sons, Chichester. 339 pp.

MURCIA, C. 1995. Edge effects in fragmented forests: implications for conservation. Trends in Ecology and Evolution 10:58-62.

NICHOLSON, D. I., HENRY, N. B. \& RUDDER, J. 1990. Disturbance regimes in North Queensland rain forests: a re-evaluation of their relationship to species richness and diversity. Australian Journal of Ecology 15:245-46.

OSTFELD, R. S. \& KEESING, F. 2000. Pulsed resources and community dynamics of consumers in terrestrial ecosystems. Trends in Ecology and Evolution 15:232-237.

PINARD, M. A. \& CROPPER, W. P. 2000. Simulated effects of logging on carbon storage in dipterocarp forest. Journal of Applied Ecology 37:267-283.

SPSS 1999. SPSS for Windows Release 9. 0. 1. SPSS Inc., Chicago.

STURMAN, A. P. \& TAPPER, N. J. 1996. The weather and climate of Australia and New Zealand. Oxford University Press, Melbourne. 476 pp.

STURTEVANT, B. R., BISSONETTE, J. A., LONG, J. N. \& ROBERTS, D. W. 1997. Coarse woody debris as a function of age, stand structure and disturbance in boreal Newfoundland. Ecological Applications 7:702-712.

TANNER, E. V. J., KAPOS, V. \& HEALEY, J. R. 1991. Hurricane effects on forest ecosystems in the Caribbean. Biotropica 23:513-521.

TER STEEGE, H. 1996. WINPHOT 5: a programme to analyze vegetation indices, light and light quality from hemispherical photographs. Tropenbos Guyana Reports 95-2, Tropenbos Guyana Programme, Georgetown, Guyana.

TRACEY, J. G. 1982. The vegetation of the humid tropical region of North Queensland. CSIRO Publications, Melbourne. $124 \mathrm{pp}$.

TURTON, S. M. 1992. Understorey light environments in a north-east Australian rain forest before and after a tropical cyclone. Journal of Tropical Ecology 8:241-252.

VANDERMEER, J., MALlONA, M. A., BOUCHER, D., YIH, K. \& PERFECTO, I. 1995. Three years of ingrowth following catastrophic hurricane damage on the Caribbean coast of Nicaragua: evidence in support of the direct regeneration hypothesis. Journal of Tropical Ecology 11:465-471.

WEBB, L. J. 1958. Cyclones as an ecological factor in tropical lowland rain forest, North Queensland. Australian Journal of Botany 6:220-228.

WHITMORE, T. C. 1974. Change with time and the role of cyclones in tropical rain forest on Kolombangara, Solomon Islands. Commonwealth Forestry Institute paper 46.

WHITMORE, T. C. 1989. Changes over twenty-one years in the Kolombangara rain forests (Solomon Islands). Journal of Ecology 77:469-515.

WHITMORE, T C. 1990. An introduction to tropical rain forests. Oxford University Press, Oxford. 226 pp.

WHITMORE, T. C. 1991. Tropical rain forest dynamics and its implications for management. Pp. 6789 in Gomez-Pompa, A., Whitmore, T. C. \& Hadley, M. (eds). Rain forest regeneration and management. UNESCO, Paris.

WhitMOre, T. G., BROWN, N. D., SWAine, M. D., KEnNEDY, D., GOODWIN-BAILEY, G. I \& GONG, W.-K. 1993. Use of hemispherical photography in forest ecology: measurement of gap size and radiation totals in a Bornean rain forest. Journal of Tropical Ecology 9:131-151. 
WILLIG, M. R. \& WALKER, L. R. 1999. Disturbance in terrestrial ecosystems: salient themes, synthesis and future directions. Pp. 747-767 in Walker, L. R. (ed.). Ecosystems of disturbed ground. Ecosystems of the World Vol. 16. Elsevier, Amsterdam.

YIH, K., BOUCHER, D. H., VANDERMEER, J. H. \& ZAMORA, N. 1991. Recovery of the rain forest of southeastern Nicaragua after destruction by Hurricane Joan. Biotropica 23:106-113. 